\title{
THE NOTION AND MEANING OF \\ INTERDISCIPLINARITY IN THE STUDIES OF ART AND MEDIA
}

\section{A B S T R A C T}

This text attempts to mark the difference between traditional, modern, monodisciplinary and contemporary interdisciplinary approaches within the analysis of reception of media and artistic contents. Monodisciplinary approaches are connected with the classical basis of humanistic and social sciences which are related to the definition of culture based on opposition between mass and elite culture (art). Avant-garde and linguistic turn within social sciences in the 60 s realized re-evaluation of the notion of culture-culture is not seen anymore as a sum of elite products of human spirit but rather as a production of cultural meaning, i.e. as a discourse. This turn enabled interdisciplinary turn within the sciences as aesthetics and art history and also enabled the emergence of contemporary interdisciplinary media theory. 
In this text, I am going to attempt, in a broad historical perspective, to mark the difference between the traditional, modernistic monodisciplinary approaches and the contemporary, interdisciplinary methodologies in studying artistic, i.e. media phenomena. The basic difference that separates classic social and humanistic approaches from the phenomenon of interdisciplinarity is a cut in the interpretation of the notion of culture. In modernistic key, culture is determined exclusively within the opposition: high, elite vs. mass culture. As opposed to this, in postmodernistic key:

Culture is spilled all over society; it becomes omnipresent even in the minutest, banal details of everyday life. Losing the aura that it gained in the modern age, ceasing to signify the special and the most valuable field of human action, postculture backs away from the concept of value, universality, quality, superiority and independence in relation to the powers of economy and politics, becoming a space where they mingle into symbolic answers of different social groups and individuals to their action. ${ }^{1}$

Classically, elitist and humanistic oriented interpretation of culture can be related to the very beginnings of modernity forming, i.e. to the beginnings of constituting social- humanistic scientific disciplines, on one hand and the concept of the autonomy of art, on the other hand. Jürgen Habermas, referring to the settings of Max Weber, considers that the modern concept of culture occurs with the Enlightenment's project: culture of modernity occurs with the separation of idea of the reason from the prevailing ideas of that time - religion and metaphysics. In the mature $18^{\text {th }}$ century, once united system of classical knowledge, i.e. theological view of the world, is separated into independent, autonomous fields of science, morals and art: human action, thus, becomes split into "special aspects of validity“- to truth, normative correctness, authenticity and beauty. Human cognition of the world becomes reduced to the issues of objective, rational knowledge, secular justice and morals and taste. Additionally, rational, exact, objective cognition of reality becomes reserved for science, while spontaneous, irrational, intuitive and expressive creation for the autonomous field of art (which is the difference that Immanuel Kant will define as a difference between the practical mind and the judgment of taste, what will become the basis of all modernistic characterizations of the work of art). According to Habermas,

Science, theories of morals, jurisprudence, production and criticism of art, could be all institutionalized. Each field of culture could respond to cultural profession where the problems would be treated as a job for special experts. This professionalized treatment of cultural tradition 
brings into focus internal structures of each of the three dimensions of culture. These structures are: cognitive-instrumental, morally-practical, aesthetically- expressive rationalities, each of them controlled by a specialist, who seems more eager than other people to follow the logic in these special fields. As a result, there is a growing distance between the culture of experts and the culture of broader audience. What becomes culture, through specialized treatment and reflexion, does not become directly and necessarily the containing element of the everyday practice. ${ }^{2}$

Therefore, this is the moment not only of establishing the modern understanding of culture as an exclusive and elite segment of human spirit and the practice of production of universal values, but also the moment of formation of theory of art in the modern sense. However, the theory of art implies different specialist disciplines developed in the autonomous social and humanistic sciences (history of art, aesthetics, sociology of art, psychology of art, etc). This is a radically new situation, because in the late 18th and the early 19th century, first of all appeared the mentioned specialization and simultaneously the metalinguistic relationship between art and culture on one hand, and science, i.e. the theory of art, on the other hand: in that sense, the theory of art is a system of "second level" language, metalanguage, whose goal is a rational, an objective, and a systematic research and explanation of the "first level" language of art. ${ }^{3}$ This division between theory, i.e. science and art, is a phenomenon that had not existed before the 18th century: moreover, before the Enlightenment, it is hard to even discuss the existence of art in the way we understand it today. In the antique period, art is reduced to a form of manual skill, which is a consequence of a specific systematization of knowledge of that time. The entire classical knowledge was organized according to seven liberal arts, i.e. Septem Artes Liberales; these seven liberal arts were divided into two groups: so-called trivium (grammar, rhetoric and logic) and so-called quadrivium (arithmetic, geometry, astronomy and music). Both of these categories made a circular, comprehensive knowledge, so-called paideia. Painting and sculpture did not belong to this group of liberal arts; the status of liberal arts these disciplines gained in the period of Renaissance with the occurrence of Studia Humanitatis. ${ }^{4}$ So, in this period, there is still no modern relationship of the separation of artistic theory and the artistic practice (metalinguistic relationship between first level language of arts and second level language of theory); exactly the opposite, in the Renaissance, both practical and theoretic segments of art served the purpose of cognition of the objective appearance of the surrounding world (an artist as a uommo universalis, and a painting as a ", window to the world“); in other words, the renaissance art is still, in the original sense ,theoretical". 
The separation between the artistic practice and the artistic theory comes with the appearance of modern aesthetics whose caring idea will exactly be the concept of the autonomy of art, in the way that Alexander Gottlieb Baumgarten defined it, and of course, Kant:

It is only in the eighteenth century, in the kind of account developed in Immanuel Kant's Critique of Judgment that we find a form of artistic evaluation that suspends other evaluative standpoints-say, of utility, politics or sensory pleasure-from which the content of a work of art may be judged. Kant does think that aesthetic values, like all values, ultimately are in some way subordinate to moral values but his characterization of the "disinterested" nature of the judgment of taste captures that response to art which is presumably left over when all other evaluative criteria are withdrawn. ${ }^{6}$

Therefore, there are three basic categories for establishing the aesthetic modernity: culture, art and the theory of art. Culture is, thus, experienced as an exquisite expression of human spirit and only the elite products of culture become objects of interest of humanistic sciences that started their establishing in the 19th century. Everything that does not belong to exquisite, high art becomes experienced as a part of popular, i.e. mass culture, which is treated as less valuable. Such an understanding of culture remains a commonplace of modernistic approaches to the analyses of society and art, from the rightoriented theorists such as Matthew Arnold and Frank Raymond Leavis, over the Marxist leftist-oriented followers of Frankfurt School (above everyone else Theodor W. Adorno and Max Horkheimer), to Kantian-established modernistic art criticism of Clement Greenberg and Harold Rosenberg:

The concept of mass society implied that on the historical scene "the crowd" had come and that the lowering of culture was a consequence of such radical realignment of the world. Parallel with the concept of mass society was emergence of the concept of mass culture that marked the new tendency towards the commercialization and industrialization of culture whose goal was the production of profit. ${ }^{7}$

The modernistic concept of culture is, thus, inseparable from the civilbourgeois conception of the autonomous art- Peter Burger, e.g. the concept of the autonomous art relates to the birth of civil society. With the conquest of power of the economically strengthened civility, rises a systematic aesthetics as a new philosophical discipline. ${ }^{8}$

Left oriented theorists of the Frankfurt School will, naturally, reject such (civil) bourgeois conception of art on behalf of the avant-garde experiment, 
but apart from that, because of the modernistic relations with the categories of aesthetic formalism and autonomy, they will still be acting within the dialectics between the high and mass culture (with the difference that the masses will be treated more as a victim and less as a cause of culture's decadence). ${ }^{9}$ Walter Benjamin is an exception who will realize the critique of the civil- bourgeois concept of culture through the thesis of reproducibility of modern mass media; he will shift the emphasis from the analysis of art object to the analysis of the reception of the work of art (and, thus, establish modern theories of reception, as well as modern theory of media) and at the same time he will open up the way to postmodernistic theories that see culture as the overall process of the production of meaning. Benjamin, thus, in his most quoted work - "The Work Of Art In The Age Of Mechanical Reproduction", makes a key-shift from the theory of art in the modern sense, towards the analysis of the mass-media culture in the postmodern sense. ${ }^{10}$

The modernistic theory of art (the philosophy of art, aesthetics, the history of art, art criticism, etc.) is seen, as in the case of aesthetics, as a group of different philosophical theories that deal with the phenomena of sensory experiences, i.e. sensory awareness "of the facts of nature, of the real and the ideally beautiful", as well as with art in the most general sense. Aesthetics in its traditional form underlines:

(i)the relationship towards art, in the narrow sense, the autonomous notion and the paradigm of art, (ii) the specific kind of cognition or the cognitive abilities(aesthesis), or more precise, that what appears in an extraordinary form that can be judged as beautiful (callistic). Thereby, Immanuel Kant in his studies of aesthetics indicates the difference between the sensory beautiful and the sensory sublime (the intellectual feeling, Geistesgefühl). ${ }^{11}$

In the case of history of art it is all about constructing the narrative,which deals, as its basic task, with the preservation, classification, chronologization, determination of style, authorship, authenticity of objects, i.e. the pieces that carry the epithet of ,artistic“. The central component of such investigation of art is a historical approach that tends towards the narrative reconstruction of the epoch in which the work rises. In the methodological sense, the history of art moves from the form analysis, on one hand, to the content analysis, on the other hand, whereby positivism of the 19th century tended towards the absolute objectivity (in order to get closer to the exactness of natural sciences) and the scientific language purified from any kind of subjectivism, i.e. the deposits of the ideological context. In short, the history of art in its classical, 
modern form involves a discipline which deals with „, styles, attribution, dating, authentication, rarities, reconstruction, detection of counterfeits, rediscovery of forgotten artists, the significance of paintings, etc" ${ }^{12}$ Finally, the phenomenon of art criticism as a kind of „derivative“ of the history of art implies:

The discipline that deals with the interpretation and evaluation of modern art phenomena, unlike the science of art history that by definition deals with art from the previous historical periods, including the one of the early modernism. Accordingly, the criticism is considered as the mediator between the world of modern art, on one hand, and the world of public, towards which the criticism is directed, on the other hand. ${ }^{13}$

In any case, the main characteristics of modernistic-based theory (or theories) of art are: 1. meta-textual relationship between the artistic practice on one hand, and the artistic theory, on the other, which actually means that art and writing about art are two completely separate and independent fields of action (art is intuitive, expressive and spontaneous, theory is rational, exact and interpretative), i.e. the interpretation of art is retrospective and it comes afterwards, after the completion of work of art by the artist (the historization of art in the history of art, i.e. the aesthetic valorization and evaluation in the art criticism); 2. elitist concept of culture, which actually means that the object of theory's interest is exclusively art, while mass, pop-culture and media remain beyond its interest (the modern theory of media comes with reshaping of modernistic and humanistic centered social sciences); 3. the analysis of art object, piece, text, i.e. psychological analysis of authorship, while the recipient and audience of the work of art mainly remain outside the interest of the artistic theory; 4. positivism, which means that theory tends towards allegedly exact and objective scientific interpretation of artistic and cultural phenomena, i.e. towards a language that would supposedly be deprived of ideological tinges and particular interests; 5. essentialism, which means that there is a supposed universal and generally applicable determination of the phenomenon of art and the work of art as an „extraordinary“ phenomenon placed within and versus the world; 6 . historicism, which means that a work of art has been analyzed, as Jauss noticed, due to the sum of its historical conditions,i.e. within the linear historical narrative as a constructed chronology; 7. formalism, which means that the work of art is viewed within the comprehensive history of style and its formal appearance. ${ }^{14}$

The question is: when did it come to destruction, i.e. deconstruction of such monodisciplinary interpretations of art? There are two central moments: the emergence of avant-garde in the 20th century art and linguistic-constructivist 
turn in the humanities that occurred in the $60 \mathrm{~s}$ and the $70 \mathrm{~s}$. Both phenomena will influence the rejection of essentialist-ontological characterization of art and re-evaluation of modernistic conception of culture.

There are numerous answers to the question in what way did avant-garde (i.e. the formations of historical avant-garde, neo avant-garde and post avant-garde) realize the critique of bourgeois conception of culture (politization of aesthetic sphere, utopian idea of blend of art and everyday life, artistic experiment, media interdisciplinarity, aesthetic of shock, rejection of the category of artistic style and its replacement by the category of artistic movement, re-evaluation of art as a social institution, etc). ${ }^{15}$ However, our interest here is in what way avant-garde influenced the deconstruction of metalinguistic (metaphysical, ontological and essentialist) relationship between art, i.e. culture on one hand, and theory, on the other, which is a central position of monodisciplinary approaches in the interpretation of art. According to Miško Šuvaković, there are two central concepts of avant-garde that deconstruct the notion of theory of art in the modernistic sense: it is the theory of an artist on one hand, i.e. the theory in art, on the other.

The theory of an artist implies a specific form of theoretical work and reflexion of art that is thought, produced, written or performed not any longer by"professional" writers of art (historians, theorists, critics, philosophers) within the intellectual division of labor in the world of art, but by artists themselves. In other words, the theory of an artist is a theoretical production that does not come afterwards, retrospectively, after the work of art is completed, but it is a theoretical work that is parallel and simultaneous with the production and creation of works of art. Moreover, it is the theoretical work that constitutes the intentions of artists and the significance/ meaning of a concrete artistic procedure.

The theory of art, in general, emerges outside the direct demands of artistic creation in specific institutions of culture (criticism, sciences about art, aesthetics and the philosophy of art, i.e. special disciplines: psychology, sociology or semiology of art). The theory of an artist, on the other hand, emerges within the very artistic practice, and it is close to interests, intentions, concepts, meanings and values of production of art inside the world of art. The theory of an artist, as an open historical discipline, appears at the same time as the theory of art, aesthetics, criticism, and the history of art during the18th century, but unlike them, it is existentially, creatively and poetically related to artistic creation and positioning of the artistic work in culture. ${ }^{16}$ 
The idea of the theory of an artist will experiencethe most significant expression within the formation of historical avant-garde and neo avant-garde, since the avant-garde theory of an artist rejects the contextual self-intelligibility of a work of art, which is a part of the idea of the autonomy of art. Contrary to the concept of the autonomy of art is the avant-garde theory of an artist performed as an intertextual practice, which means that the writings of artists and the theories of artists are not closed structures, but they are exposed to influences of other discourses and texts. ${ }^{17}$ In other words, the theory of an artist shows that art is not an isolated and self-involving phenomenon, but a process, a practice conditioned by social-historical context, i.e. culture in the most general sense.

The theory in art implies, above all, the legacy of conceptual art of the 60s and the 70s which in the spirit of „,dematerialization of art object" rejected the production of art as the creation of finished art objects (paintings, sculptures, graphics etc.), and replaced the category of work of art with the category of philosophical, aesthetic and theoretical discussion. ${ }^{18}$ In that sense, with the appearance of conceptualism the status of theory of art has changed: theory is no longer a part of subsequent and retrospective interpretation of finished/ complete works of art (theory as a metalanguage and a secondary interpretation), but the creation of theory and the creation of art become a part of the unique and complete process. The projects of the conceptual artists mostly do not tend towards the production of art objects, but they tend to answer the question: "what is art?", and what are the boundaries of art as a social practice? Inspired primarily by Ludwig Wittgenstein's analytic theory of language, and then by the linguistic reversal that poststructuralism brought, conceptual artists give a radically relativistic, an anti-essentialist and a constructivist answer: art is a form of linguistic, cultural, theoretical, ideological, historical and social consensus, i.e. construct. This process is minutely explained by a conceptual artist and a theorist Victor Burgin. Referring to the argumentation of French poststructuralist theory, Burgin considers that conceptual art contributed to a definitive delegitimization of modernistic canons of aesthetics and the history of art where the idea of the autonomy of art was implied. Art is in the intertextual overlap with the context in which it emerges, i.e. art is not a concrete, autonomous object, but a form of production of meaning, i.e. discourse. Conceptual art, thus, deals exclusively with material presentations of the discourse of art, and it rejects the existence of the autonomous ontological characterization of a work of art, i.e. conceptual artists subvert modernistic systems of the legitimization of art. At the same time, as it has already been mentioned, theory is no longer a part of a secondary language in regard to the artistic practice, a part of metanarrative of the „objective“ knowledge, but 
rather art and theory have become a relativistic, anti-essentialist and critical analysis of culture in the broadest sense. ${ }^{19}$

Thus conceptualism, with its practice of theory in art,contributed to reshaping of the concepts of art and culture: art definitively lost its privileged position as an autonomous, disinterested concept and an elitist product of human spirit and all because it became part of culture in the broadest sense. While modernism interprets culture in the context of the opposition between high and mass culture, within postmodernistic key, culture is interpreted exclusively as a group of signifying social practices; in that sense, culture is a complex system of overlapping and confronting different discursive formations. Art has become a practice of analysis of a current social context within culture seen as a system of language. This is a key position that has been reached by both conceptual artists and theorists of constructionist orientation (primarily, French post-structuralism, and under its influence, somewhat later, British cultural studies): culture is no longer experienced as a group of elite artifacts that give „essence“ to history in general development of human spirit, i.e. as a civilizational criteria of the highest order, a guide „through the fog of everyday experiences and the banality of life ${ }^{\text {"20 }}$, but the culture is interpreted as discourse.

Discourse is, thus, a central notion of the constructionist-relativistic theory of culture, i.e. of structuralist and post-structuralist theories:

In the beginning discourse, according to Benveniste, was considered as a sort of statement where all the signs and traces of expression were present. Then, the discourse implied the speech ,out of context", that brought and discovered all the characteristics of power, ideology, the nature of carriers of the discourse. In that sense, discourse is a speech of a social group, institution or society, thus, Faucault establishes a discursive analysis as ,a discussion/ debate about techniques of expression, interpretation, representation of social and historical identities of knowledge in the Western culture." (Šuvaković). ${ }^{21}$

That is how monodisciplinary, essentialist and modernistic founded theory of art experiences its end and becomes transformed into interdisciplinary theory of culture. Its basic characteristics have become: 1. interdisciplinarity, which means that modern studies of art and media are a complex intertextual philosophical and theoretical platform that has not been applied any longer within narrow disciplinary framework (beauty in aesthetics, art in the history of art, mental processes of creation, and receptions in the psychology of art, 
etc.), but the object of interest of modern theory of culture is a whole range of cultural phenomena that appear in the mutual overlap and which modernism saw as separate and autonomous fields of human action (art, literature, music, pop culture, media, fashion, clothes, food, means of mass communication, etc); 2. anti-essentialism, which means that there is no ontological foundation of the notion of art, but that art is a social construct, a practice, i.e. that in our cognition of the world we do not work with the phenomena themselves, but our cognition of the world is always mediated by language, i.e. culture; 3 . anti- positivism, which means that there is no absolute „objective“ scientific language, but the speech always contains the relations of power, so that the goal of interdisciplinary theory of culture is a deconstruction of relations of power within a concrete historically determined society (these relation can refer to class, race, gender, generation, etc.); 4. a shift in the level of analysis from the artistic object to the recipient. The receiver, the recipient of artistic and media contents thus becomes a leading category of modern studies of culture, art and media.

This shift from monodisciplinarity towards interdisciplinarity, from essentialism towards constructivism, from the analysis of aesthetic phenomena towards the theory of reception is a process through which all the humanistic disciplines pass: aesthetics as a science about sensory, i.e. beautiful, becomes transformed into intertextual theory of culture, ${ }^{22}$ the history of art becomes transformed into so-called "new art history“ ${ }^{\prime 23}$ and a modern theory of media has been established as a scientific discipline. ${ }^{24}$ Writing about cultural phenomena thus becomes a complex intertextual flow through spaces of aesthetics, history of art, theory of media, and theory of culture, in the most general sense.

German theorist Wolfgang Welsch writes about the changes that occurred within aesthetics as an autonomous philosophical discipline. According to him, traditional, monodisciplinary founded aesthetics is an autonomous discipline, that above all deals with the notion of beautiful, i.e. with the general principles of art. Being such, modernistic aesthetics, despite some exceptions, becomes concentrated exclusively on the phenomenon of art. Basic lack of such determined discipline is primarily universal(istic) concept of art- instead of the universal notion, today, we can exclusively discuss about the different versions and concepts of art- classic aesthetics, thus, primarily overlooking the fact that that there is no ,essence of art“. Monodisciplnary aesthetics has today been overcome, because in modern, consumer societies there occurs obvious global deterritorialization and reconfiguration of the aesthetic- the notion of the aesthetic is no longer reserved for art exclusively, but for the 
whole everyday life ( body embellishment, creation of media-generated reality, etc.). Today's society is a system of domination of a media-generated image, where the difference between representation and simulation has been lost. ${ }^{25}$ Simultaneously, the ocularcentric domination of vision and seeing, which is the assumption upon which originally aesthetics has been founded since

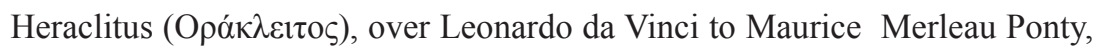
under the influence of media-generated spectacle, comes to its end- within the media-generated society and in media-simulated reality it is no longer possible to discuss about the hierarchy of senses; in that sense, hearing, e.g.

is being appreciated anew because of its anti-metaphysical proximity to the event instead of to permanent being, because of its essentially social character in contrast to the individualistic execution of vision, and because of its link with emotional elements in opposition to the emotionless mastery of phenomena through vision. ${ }^{26}$

Therefore, derealisation of reality, reconfiguration of aisthesis and the whole new system of sensory sensations in modern society of spectacles (a change in perception of aesthetic phenomena), direct us towards transformation of aesthetics as a discipline: the new aesthetics implies the fact of different meanings and different contexts where the phenomenon of the aesthetic occurs - from art, over mass media and means of communication, all the way to everyday life within the contemporary postmodern consumer society. Aisthesis has no longer unambiguous, but utterly multivalent meaning that aesthetics as a discipline must take into consideration. Thus, it comes to overlapping with other disciplines, and to institutional broadening of the framework of aesthetics as a science. Its framework is no longer exclusively art, especially because today the idea of the autonomy of art has largely been rejected, and art has become an open media concept, where the works of art have lost their contemplative foundation. In other words, the reception of art is poliaesthetic, and not any longer monoaesthetic, i.e. today it is possible to discuss exclusively about transdisciplinary aesthetics:

Finally, what will the structure of the discipline of aesthetics be in the wake of such an expansion? My answer is surely not surprising: its structure will be transdisciplinary. I imagine aesthetics being a field of research which comprehends all questions concerning aisthesis with the inclusion of contributions from philosophy, sociology, art history, psychology, anthropology, neurosciences, and so on. Aisthesis forms the framework of the discipline. And art is one-but, as important as it might be, only one-of its subjects. ${ }^{27}$ 
It comes to similar changes within the history of art that has been transforming into so-called new art history, or, as asaslo called the implosion of interdisciplinarity into this classical discipline, into „critical“, i.e. „radical“ history of art. The phenomenon of the new art history emerges during the $80 \mathrm{~s}$, when methodological basis of the discipline was transformed. Those transformations include backing away from the historical and formalistic approaches towards a) Marxist and Post-Marxist theory of history, politics and society, b) feministic theory and criticism of patriarchy and woman's position within historical and current societies, c) psychoanalytic, primarily, Lacanian thesis about the visual representation and constitution of the social and sexual identity and d) semiologic and structuralistic concepts and methods in the analysis of signs and meanings. ${ }^{28}$

According to Jonathan Harris, the beginnings of the new history of art are related to the theoretic deconstruction of the modernistic notion of the autonomy of art and the modernistic concept of the elite culture introduced by Marxist and feminist oriented historians of art of the 70s, such as Timothy James Clark, i.e. Fred Orton and Griselda Pollock. These historians will start defining the social, materialistically oriented history of art in deconstructionist, relativistic and constructivist key:

One of the first rules that have been questioned was the rule of leaving out women artists from the canons of classical history of art. Now then followed the contextualization of the works of art, as well as the issue of limitation of the interpretative apparatus that was excluding the analyses of ideological, socio-political, psychoanalytic, racial and class theories. The prevailing feeling of the 70s was the fear that history of art, since its beginnings, had been dominated by a master discourse or canon, which, at the same time, had been speaking from the position of man and power. ${ }^{29}$

Finally, practically in the same period, there comes to establishment of the new discipline, related to the modern theory of culture- the interdisciplinary theory of media. The theory of media, as a discipline started with the establishment in the $60 \mathrm{~s}$, in different methodological fields: the constitutive role will certainly be played by American theorist Marshall McLuhan whose theses would overlap with the settings of the theorist of communication Harold Innis. The second „source"of modern theory of media is the theory of information that develops under the influence of cybernetics and the thinkers such as Claude Shannon and Gregory Bateson. In the end, one should also mention the philosophy of symbolic forms of Ernst Cassirer and Susanne K. Langer. 
Media theory as it is taught in art schools, colleges and universities contains three main currents. The first emanates from film and television studies and cultural studies with a focus on visual culture. The second springs from literary studies (...) an important third current is borne by artists producing machine art, interactive installations and network art, but also by non-university intellectuals who practice speculative media theory. ${ }^{30}$

However, approaches within modern theory of media can be divided into: general history of media, primarily based on the settings of Marshall McLuhan, who places the accent in the analysis not on the content of the media message, but on the medium itself (e.g. the representation of reality in painting is an illusionist representation, while exclusively material appearance of the image is what we experience as a message, a medium; related to this is McLuhan's maxima-,,medium is the message“). In that way, the three levels of the communicative act, between the recipient and the medium, are important: the level of information (the technical level), the level of symbolic meaning (the semantic level), and finally, the social level that implies the influence of media on forming social relationships ${ }^{31}$ McLuhan, thus, makes the difference between different media due to the quantity of information that the recipient receives through the communicational act via media: on one hand, there are cold media (they demand a certain dose of imagination from the recipient), and on the other hand, there are hot media (they give full, saturated information, by bombing the senses of the recipient, and not demanding his/her imagination). ${ }^{32}$ The next to follow is a very important approach within the theory of media, the historical, that follows the social history of different media and their influence on social relationships in a concrete historical moment (e.g. in what way the development of writing had the influence on founding The Roman Empire in the old century, or in what way the development of mass media had influence on the formation of Nazism in Germany in 30's). ${ }^{33}$ In the end, we can discuss about practical or applied theory of media which deals with concrete media forms and their specificities (the theory of photography, the theory of television and radio, the theory of new media, etc.). Finally, a special segment, especially when the reception of artistic and media contents issues are in question, represent modern studies of audience that stem from the studies of subcultures developed within the British cultural studies, over the analyses of fans, the gender theories of audience, all the way to the theories of virtual communities within the interactive space of the digital media (cyberspace, internet, video games, etc.). ${ }^{34}$ 

teorije posle 1950, (Belgarde and Novi Sad: Srpska Akademija nauka i umetnosti and Prometej, 1999), 348-350. (New York: Humanities Press International, 1986), 140-204. Studies, eds. Michael Ann Holly and Keith Moxey (Massachusetts: Sterling and Francine Clark Institute, 2002), 105-121.

Peter Birger, Teorija avangarde (Beograd: Narodna knjiga, 1998). estetici, teoriji i studijama umetnosti i kulture (Beograd: Univerzitet umetnosti u Beogradu, 2006), 69-70.

Branislava Anđelković, „Istorija umetnosti i feminističke teorije slike,“ u Uvod u feminističke teorije slike (Beograd: Centar za savremenu umetnost, 2002), 9.; see also: Robert S. Nelson i Ručard Šif (ur.), Kritički termini istorije umetnosti (Novi Sad: Svetovi, 2004).

Ješa Denegri, „Kritika u tekstu i kritika na delu,“ Treći program 145(2010): 284-292.

Hans Robert Jaus, „Istorija umetnosti i opšta istorija,“ u Estetika recepcije-izbor studija (Beograd: Nolit, 1978), 89-125.

see: Peter Birger, Teorija avangarde, (Beograd: Narodna knjiga, 1998); Renato Pođoli, Teorija avangardne umetnosti (Beograd: Nolit, 1975); Mikloš Sabolči, Avangarda i neoavangarda (Beograd: Narodna knjiga, 1997); Hal Foster, The Return of the Real. The Avant-Garde at the End of the Century (Cambridge: The MIT Press, 1996).

Miško Šuvaković, Diskurzivna analiza. Prestupi i/il pristupi 'diskurzivne analize’filozofiji, poetici, estetici, teoriji i studijama umetnosti i kulture, Univerzitet umetnosti u Beogradu, Belgrade, 2006,p. 313

ibid.

see: Alexander Alberro and Blake Stimson (eds.), Conceptual art: A Critical Anthology (Cambridge, Massachusetts/London, England: The MIT Press, 2000).

Victor Burgin, „The End of Art Theory,“ In The End of Art Theory: Criticism and Postmodernity,(New York: Humanities Press International, 1986), 140-204.

Jelena Đorđević, Postkultura, 26.

Nevena Daković, predgovor u Estetika filma; Žak Omon, Alen Bergala, Mišel Mari, Mark Verne (Beograd: Clio, 2006), 297.

Wolfganag Welsch, Undoing Aesthetics (London: Sage Publication, 1997); Aleš Erjavec, „Aesthetics: Philosophy of Art or Philosophy of Culture,“ Filozofski vestnik št. 2, (2001): 7-30; Miško Šuvaković i Aleš Erjavec (ur.), Figure u pokretu. Savremena zapadna estetika, filozofija $i$ teorija umetnosti (Beograd:Vujičić kolekcija, 2009); Žan Kon, Estetika komunikacije (Beograd: Clio, 2001).

Robert S. Nelson i Ručard Šif (ur.), Kritički termini istorije umetnosti (Novi Sad, Svetovi, 2004); Jonathan Harris, The New Art History. A Critical Introduction (London and New York: Routledge, 2006); Michael Ann Holly and Keith Moxey (eds.), Art History, Aesthetics, Visual Studies (Massachusetts: Sterling and Francine Clark Institute, 2002); Branislava Anđelković (ur.), Uvod u feminističke teorije slike (Beograd: Centar za savremenu umetnost, 2002). 
Arien Mulder, Understanding Media Theory. Language, Image, Sound, Behavior (Roterdam: NAi Publishers/V2-Organization, 2004); Daglas Kelner, Medijska kultura. Studije kulture, identitet $i$ politika između modernizma i postmodernizma (Beograd: Clio, 2004); Adam Brigs, Pol Kobli (ur.), Uvod u studije medija (Beograd: Clio, 2005). see: Marina Gržinić, „Simulacija i filozofski rad Jeana Baudrillarda,“ u U redu za virtuelni kruh (Zagreb: Meandar, 1998), 138-165.

Wolfganag Welsch, „Aesthetics Beyond Aesthetics. For a New Form to the Discipline, “ In Undoing Aesthetics (London: Sage Publication, 1997), 87. ibid.

Jonathan Harris, The New Art History. A Critical Introduction (London and New York: Routledge, 2006), 7.

Branislava Anđelković, „Istorija umetnosti i feminističke teorije slike,“ u Uvod u feminističke teorije slike (Beograd: Centar za savremenu umetnost, 2002), 11-12.

Arien Mulder, Understanding Media Theory. Language, Image, Sound, Behavior (Roterdam: NAi Publishers/V2-Organization, 2004), 8.

ibid.

see: Marshall McLuhan, Understanding Media, The Extensions of Man (London and New York: Routledge, 2005).

Jelena Đorđević, "Popularna kultura," u Postkultura (Beograd: Clio, 2009); Elizabeth Bird, The Audience in Everyday Life. Living in a Media World (London and New York: Routledge, 2003); Richard Butch, The Citizen Audience. Crowds, Publics, and Individuals (London and New York: Routledge, 2008); Stiven Džouns (ur.), Virtuelna kultura (Beograd: XX vek, 2001).

Alberro, Alexander and Blake Stimson (eds.), Conceptual art: A Critical Anthology. Cambridge/ Massachusetts/London: The MIT Press, 2000.

Anđelković, Branislava (ed.), Uvod u feminističke teorije slike. Belgrade: Centar za savremenu umetnost, 2002.

Benjamin, Walter, "Umetničko delo u veku svoje tehničke reprodukcije", u Eseji. Beograd: Nolit, 1974.

Bird, Elizabeth. The Audience in Everyday Life. Living in a Media World. London/ New York: Routledge, 2003.

Birger, Peter. Teorija avangarde. Beograd: Narodna knjiga, 1998.

Blant, Entoni. Umetnička teorija u Italiji 1450-1600. Beograd: Clio, 2004.

Brigs, Adam and Pol Kobli (eds.), Uvod u studije medija. Beograd: Clio, 2005.

Brigs, Asa and Peter Berk. Društvena istorija medija. Beograd: Clio, 2006.

Burgin, Victor. The End of Art Theory: Criticism and Postmodernity. New York: Humanities Press International, 1986.

Butch, Richard. The Citizen Audience. Crowds, Publics, and Individuals. London/ New York: Routledge, 2008. 
Daković, Nevena, afterword in the book Žak Omon, Alen Bergala, Mišel Mari, Mark Verne, Estetika filma. Beograd: Clio, 2006.

Denegri, Ješa. „Kritika u tekstu i kritika na delu“, Treći program br. 145, Belgrade, 2010, p. 284292.

Džouns, Stiven (ed.), Virtuelna kultura. Beograd: XX vek, 2001

Đorđević, Jelena. Postkultura. Beograd: Clio, 2009.

Erjavec, Aleš, „Aesthetics: Philosophy of Art or Philosophy of Culture“, Filozofski vestnik št. 2, Ljubljana, 2001, p. 7-30.

Foster, Hal. The Return of the Real. The Avant-Garde at the End of the Century. Cambridge, Massachusetts/London, England :The MIT Press, 1996.

Gilmore, Jonathan, „Censorship, Autonomy, and Artistic Form“, Michael Ann Holly and Moxey, Keith (eds.), Art History, Aesthetics, Visual Studies., Massachusetts: Sterling and Francine Clark Institute, 2002.

Gržinić, Marina. U redu za virtuelni kruh. Zagreb: Meandar, 1998.

Habermas, Jürgen, „Modernost-jedan necelovit projekat“, Projeka(r)t no. 11-15, Novi Sad, march 2001.

Harris, Jonathan. The New Art History. A Critical Introduction. London/ New York: Routledge, 2006.

Holly, Michael Ann and Keith Moxey (eds.), Art History, Aesthetics, Visual Studies. Massachusetts: Sterling and Francine Clark Institute, 2002.

Jaus, Hans Robert, „Istorija umetnosti i opšta istorija“, u Estetika recepcije-izbor studija. Beograd: Nolit, 1978. p. 89-125

Kelner, Daglas. Medijska kultura. Studije kulture, identitet i politika između modernizma $i$ postmodernizma. Beograd: Clio, 2004.

Kon, Žan. Estetika komunikacije. Beograd: Clio, 2001.

McLuhan, Marshall. Understanding Media, The Extensions of Man.London/ New York: Routledge, 2005

Mulder, Arien. Understanding Media Theory. Language, Image, Sound, Behavior. Rotherdam: NAi Publishers/V2-Organization, 2004.

Nelson, Robert S. and Ručard Šif (eds.), Kritički termini istorije umetnosti. Novi Sad: Svetovi, 2004.

Pođoli, Renato. Teorija avangardne umetnosti. Beograd: Nolit, 1975.

Sabolči, Mikloš. Avangarda i neoavangarda. Beograd: Narodna knjiga, 1997.

Šuvaković, Miško i Aleš Erjavec (ur.), Figure u pokretu. Savremena zapadna estetika, filozofija $i$ teorija umetnosti. Beograd: Vujičić kolekcija, 2009.

Šuvaković, Miško. Diskurzivna analiza. Prestupi i/il pristupi 'diskurzivne analize’ filozofiji, poetici, estetici, teoriji i studijama umetnosti $i$ kulture. Beograd: Univerzitet umetnosti u Beogradu, 2006.

Šuvaković, Miško. Pojmovnik moderne i postmoderne likovne umetnosti i teorije posle 1950. Beograd/ Novi Sad: Srpska Akademija nauka i umetnosti and Prometej, 1999.

Vellmer, Albreeht, „Istina, privid, pomirenje (Adornovo estetičko spasavanje moderniteta)“, Estetička teorija danas. Sarajevo: IP Veselin Masleša, 1990. p. 255-291

Welsch, Wolfganag. Undoing Aesthetics. London: Sage Publication, 1997. 


\section{PROSTORI RAMIMOILAŽENJA}

\section{Barbara Steiner}

Ovaj tekst postavlja pitanje kako neslaganje može prostorno da se organizuje. Premda, uzimajući nedavne razvoje u umetnosti, arhitekturi i urbanom planiranju u razmatranje, $u$ fokusu su dva projekta umetnice i arhitekte Apolonije Šuštrešič: kafe KAFIČ, koji je naručila Galerie für Zeitgenössische Kunst Leipzig i (Community Pavillion) Paviljon zajednice u Hustadtu, koji je naručila opština Bochum. Prateći ova dva primera ovaj tekst razmatra mogućnosti kako da se društveni antagonizam preobrazi u agonizam time kreirajući živahnu javnu sferu koja dozvoljava izražavanje takmičarskih pojmova, mišljenja i prilaza.

KLJUČNE REČI: NESLAGANJE, KONFLIKT, RAZILAŽENJE, JAVNI PROTSOR, ANTAGONIZAM, AGONIZAM

POJAM I ZNAČENJE MEĐUDISCIPLINARNOSTI

U PROUČAVANJU UMETNOSTI I MEDIJUMA

\section{Nikola Dedić}

Ovaj tekst pokušava da označi razliku između tradicionalnih, modernih monodisciplinarnih i savremenih međudisciplinarnih prilaza u okviru analize prijema medijskih i umetničkih sadržaja. Monodisciplinarni prilazi su povezani sa klasičnom osnovom humanističkih i društvenih nauka koje su povezane sa defincijom kulture zasnovanom na suprotnosti masovne i elitne kulture (umetnosti). Avant-gardni i lingvistički preokret u okvru društvenih nauka šezdesetih je realizovao ponovno prosuđivanje vrednosti pojma kulture - kultura se više ne posmatra kao zbir elitnih proizvoda ljudskog duha već pre kao proizvodnja kulturnih značenja, tj. kao diskurs. Ovaj preokret je omogućio međudsiplinarni preokret u okviru nauka kao što je estetika i istorija umetnosti $\mathrm{i}$ isto tako omogućio pojavu savremene, međudisciplinarne teorije medija.

KLJUČNE REČI: MONODSCIPLINARNOST, MEĐUDISCIPLINARNOST, MODERNIZAM, POSTMODERNIZAM, TEORIJA UMETNOSTI, ESTETIKA, ISTORIJA UMETNOSTI, AVANT-GARDA, TERIJA MEDIJA, PROUČAVANJA KULTURE

TRI SEKVENCE PISANJA-LOKACIJE

\section{Angela Harutyunyan}

Ovaj članak obuhvata tri vežbe/zadatka „pisanja lokacije“ prekinuta teoretskim i metodološkim pauzama. Ove sekvence odvode čitaoca u topografska i eksegetička putovanja u razne slike, tragove memorije i priče koji tretiraju 